\title{
Molecular Barcoding Reveal the Existence of Mole Crabs Emerita emeritus in North Coast of Central Java
}

\author{
Dian Bhagawati, Elly Tuti Winarni, Agus Nuryanto* \\ Faculty of Biology, Universitas Jenderal Soedirman, Indonesia \\ *Email: anuryanto2003@yahoo.com
}

Submitted: 12 August 2019. Revised: 11 January 2020. Accepted: 20 March 2020

\begin{abstract}
The existence of mole crabs had been reported from the southern coast of Central Java. However, no mole crab data was available from the northern coast of Central Java. This study aimed to figure out the existence of mole crabs on the northern coast of Central Java, as revealed from the cytochrome c oxidase 1 (COI) barcoding. Mole crabs samples collected in Sendang Sikucing Beach Kendal. The taxonomic status of the samples was inferred from sequences similarity test using the basic local alignment search tool to conspecific sequence deposited in GenBank. Pairwise genetic distances were calculated based on the Kimura 2-parameter model. A phylogenetic tree had reconstructed in molecular evolutionary genetic analysis (MEGA) software based on a neighbor-joining algorithm. Branching reliability was obtained from 1000 bootstraps replication, while branching polarity was obtained from the out-group comparison. The mole crab samples from the northern coast of Central Java had unambiguously identified as Emerita emeritus based on high sequences similarities (98.27\%-99.70\%). The decision was supported by low genetic distances (0.002-0.005) and their monophyly with Emerita emeritus (KR047035) in GenBank. Pairwise analysis among each possible pair of samples had genetic distances ranged between 0.000 and 0.005 , indicated that all sample belongs to single species. The data provide the first record of the existence of Emerita emeritus on the northern coast of Central Java. Our data on the existence of E. emeritus on the northern coast of Central Java is among essentials information as a scientific basis in creating policy for the management of sustainable use of the mole crabs in the areas.
\end{abstract}

Key words: COI Barcoding, Emerita, Kendal beach, Central Java

How to Cite: Bhagawati, D., Winarni, E. T., \& Nuryanto, A. (2020). Molecular Barcoding Reveal the Existence of Mole Crabs Emerita emeritus in North Coast of Central Java. Biosaintifika: Journal of Biology \& Biology Education, 12 (1), 104-110

DOI: http://dx.doi.org/10.15294/biosaintifika.v12i1.20497

\section{INTRODUCTION}

Mole crabs or sand crabs from superfamily Hippoidea are widely distributed over the World. This macrozoobenthos buried under the sand surfaces at the intertidal zone (Wardiatno et al., 2016; Bhagawati et al., 2016; Pramithasari et al., 2017). It had reported that mole crabs play an important role in the intertidal zones of tropical and subtropical regions to stabilize the food chain in the marine environment (Wilson \& Wolkovich, 2011; Beasley et al., 2012; Lastra et al., 2016).

Hippoidea is divided into three different families, e.g., Albuneidae, Blepharipodidae, and Hippidae. Albuneidae consisted of one genus of Albunea. Hippidae consisted of Emerita and Hippa (Boyko \& McLaughlin, 2010). Ten species of Emerita have been described from all over the universe (Boyko \& McLaughlin, 2010), and their distribution has been summarized by Mahapatro et al. (2018). Three genera of Hippoidea reported from Indonesia waters; i.e., Albunea, Emerita, and Hippa (Bhagawati et al., 2016; Pramithasari et al., 2017).

Previous studies reported that various species of mole crabs inhabit Indonesia's coastal areas. Five species of Hippa that have been described from Indo- nesia that are $H$. adactyla, $H$. admirabilis, $H$. ovalis, $H$. marmorata, and $H$. celaeno (Wardiatno et al., 2014; Muzammil et al., 2015). Other species of mole crab reported from the southern coast of Java Island. For instance, Pramithasari et al. (2017) found Albune symmysta from intertidal zones of Samas and Congot beaches in Yogyakarta. E. emeritus was reported from Bulus Pesantren Beach Kebumen Regency (Mashar \& Wardiatno, 2013) and other offshore areas on the southern coast of Java Island (Wardiatno et al., 2015).

Morphological identification of mole crabs has a long-standing impediment due to high morphological variability within species (Rudolf et al., 2016). Therefore, accurate species-level identification of mole crab needs an additional method. The identification method with a highly precise result can be performed through molecular identification using cytochrome $\mathrm{c}$ oxidase 1 (COI) barcode. The COI barcode has been widely used in animal identification (Ward et al., 2009; deWard et al., 2011). In DNA barcoding, species identification is based on the genetic distance of 2 to $3 \%$ (Hubert et al., 2012) or even genetic distance among individuals within species that might reach of $6.8 \%$ up to $24.8 \%$ depending on the fish group (Pereira et al., 2013). 
Several studies had successfully identified animals into species-level depend on the availability of reference sequences in the database. For example, Nuryanto et al. (2017) were successfully identified fish larvae specimens until species level. Other studies also proved that the partial sequence of the COI gene as a reliable marker for species determination in crustacean (Weiss et al., 2014; Raupah 2015; Matelatto et al., 2016).

All previous studies on mole crabs in Indonesia had performed either outside of Java Island or on the southern coast of Java. No study reported the existence of mole crabs from the northern coast of Java, neither based on morphology nor molecular identification. Therefore, taxonomic study through deep and careful identification is a vital step to explore the existence of mole crabs on the northern coast of Java and to ensure which species exist. This study aimed to explore the existence of mole crabs on the northern coast of Java Island with special emphasis in northern Central Java. Molecular identification was chosen due to the nature of mole crabs that showed high morphological divergence within species.

The data obtained is essential as a scientific basis for decision-making to create regulation on sustainable use of mole crabs on the north coast of Java. The data extended the reliability of the COI gene as an identification tool in a taxonomic study with the consequences of improving the importance of taxonomic study in the applied field of science.

\section{METHODS}

\section{Sampling site}

Mole crab samples were collected using incidental sampling techniques in Sendang Sikucing Beach, District of Weleri, Kendal Regency (Figure 1). Sample collection was performed using push nets (locally known as jaring sodo) and helped by local fishermen. Field trips had conducted in March, April, and September 2019.

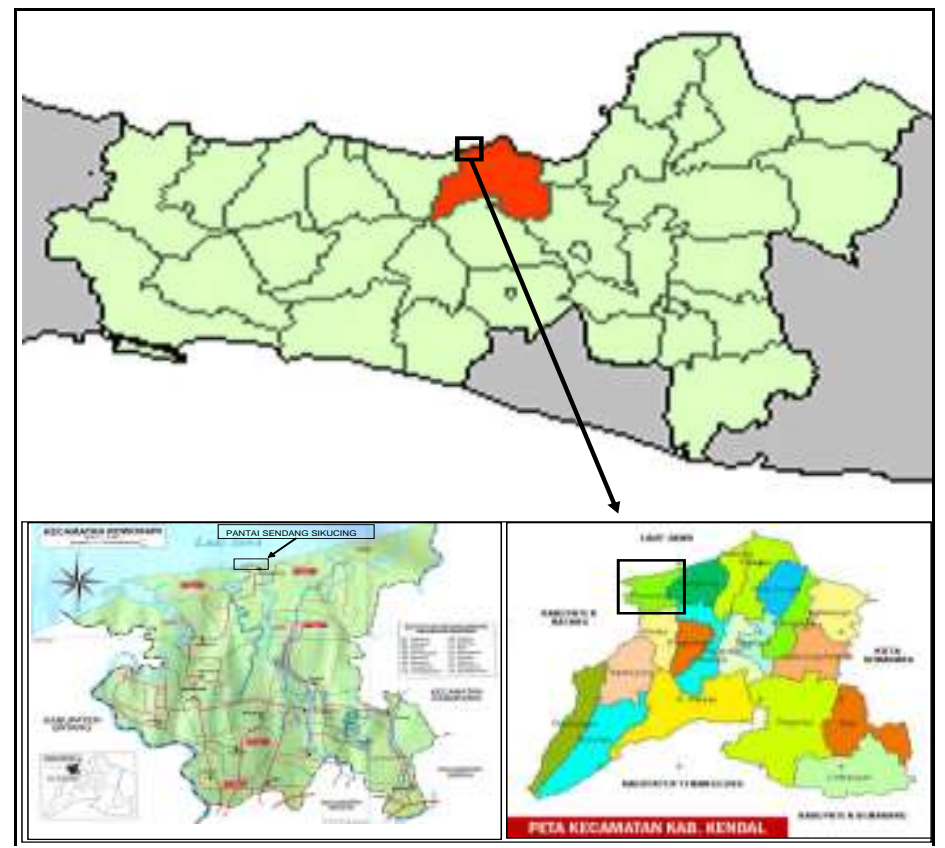

Figure 1. Sampling site in Sendang Sikucing Beach (Source: Legend)

\section{Sample Handling}

The whole individual of mole crab samples was preserved in ethanol $70 \%$ for morphological observation. A small fraction of pereopod was cut off and preserved in $96 \%$ pro analytic ethanol for molecular identification.

\section{DNA Isolation, Amplification, and Sequencing}

The isolation of total DNA, PCR amplification, and sequencing of the partial sequences of the COI barcode were performed at $1^{\text {st }}$ BASE (www.baseasia.com, No 7-1 to 7-4, Jalan SP 2/7 Taman Serdang
Perdana, Seksyen 2, Seri Kembangan 43300, Selangor, Malaysia). The partial sequences of COI barcode were multiplied in polymerase chain reaction technique using metazoan universal primer LCO1490:5'GGTCAA CAAATCATA AAG ATATTG G-3'dan HCO2198:5'-TAA ACTTCAGGG TGA CCA AAA AAT CA-3' (Folmer et al., 1994).

\section{Data Analysis}

The nucleotide sequences of the partial COI gene were edited and aligned together using Bioedit software (ver. 7.0.5; Hall, 1999). Sequences alignment 
was conducted using ClustalW (Thompson et al., 1994) in Bioedit ver. 7.0.5; Hall, 1999). Functional cytochrome c oxidase 1 gene was determined by translating the nucleotide sequences to an amino acid in ORFfinder online software (https://www.ncbi.nlm.nih.gov/orffinder/; National Center for Biotechnology Information, U.S. National Library of Medicine 8600 Rockville Pike, Bethesda MD, 20894 USA). Taxonomic status of the samples obtained from the homology test to the conspecific sequences data deposited in GenBank (https://www.ncbi.nlm.nih.gov/orffinder/; National Center for Biotechnology Information, U.S. National Library of Medicine 8600 Rockville Pike, Bethesda MD, 20894 USA). Additional data of genetic distances and monophyly of the samples were calculated in MEGA X (Kumar et al., 2018). Genetic distances and monophyly of the samples were estimated based on the Kimura-2 Parameter (K2P) model of evolution. The polarity of tree branches was obtained from other mole crab species (Albunea symysta MG930985, Albunea paretii MF490048, Albunea gibbessi MF490047) and out-group comparisons. Scylla serrata (accession number KM528133) had used as outgroup species. The reliability of the branching pattern was obtained through 1000 non-parametric pseudoreplicates.

\section{RESULTS AND DISCUSSION}

The taxonomic status of the samples was defined based on the homology values of the sample sequences compared to the reference sequences deposited in GenBank. The homology test of four female and four individual male samples used Basic Local Alignment Search Tool (BLAST) showed that the samples had homology value ranged between 98.27 and 99.98 to the sequence of $E$. emeritus (accession number KR047035). Complete data on sequences homology and the taxonomic decision of the sample to the conspecific sequence are presented in Table 1.

It can be seen in Table 1 that all samples had sequence homologies higher than $97 \%$ and sequence divergences to the reference species less than $3 \%$. According to those either homology values or sequence divergences, the mole crabs samples from the northern coast of Central Java were undoubtedly determined as E. emeritus. High genetic homology among crustacean specimens with reference conspecific sequences and low sequence divergence among individuals have also been reported in another study (Bilgin et al., 2014). High genetic homology among individuals within species was also reported in fish (Nuryanto et al., 2017; Ko et al., 2013). However, comparing to study form Nuryanto et al. (2017) and Ko et al. (2013), did not hundred percent parallel since our present study and the study from Nuryanto et al. (2017) and Ko et al. (2013) were used different research objects. Here we used mole crab as a research object, while Nuryanto et al. (2017) and Ko et al. (2013) used fish larvae as their research objects. However, from that comparison, we obtained insight that different groups of animals might show a variable value of genetic homology and divergences within species. It proved by da Silva et al. (2011) and Bucklin et al. (2010) that different group animal species showed highly variable genetic homology and differences among intraspecific individuals. All those previous studies strengthen our decision that the mole crab samples from the northern coast of Central Java belong to E. emeritus.

Kimura 2-parameter (K2P) genetic distance analysis showed a low value of genetic distances either among mole crabs samples with reference sequences in the database or among each pair of the samples. Those genetic distance values were much lower compared to that value among species of Hippoidea (Table 1).

Table 1. Sample code, homology values of the samples, and taxonomic decision

\begin{tabular}{lllll}
\hline Code & Homology (\%) & Seq.Div. (\%) & Reference Species & Taxonomic decision \\
\hline W1 & 99.55 & 0.45 & Emerita emeritus KR047035 & Emerita emeritus \\
W2 & 99.70 & 0.30 & Emerita emeritus KR047035 & Emerita emeritus \\
EWB1 & 98.98 & 1.02 & Emerita emeritus KR047035 & Emerita emeritus \\
EWB2 & 99.12 & 0.88 & Emerita emeritus KR047035 & Emerita emeritus \\
EWB3 & 99.26 & 0.74 & Emerita emeritus KR047035 & Emerita emeritus \\
EWJ1 & 99.41 & 0.59 & Emerita emeritus KR047035 & Emerita emeritus \\
EWJ2 & 98.27 & 1.73 & Emerita emeritus KR047035 & Emerita emeritus \\
EWJ3 & 99.55 & 0.25 & Emerita emeritus KR047035 & Emerita emeritus \\
\hline
\end{tabular}

Remarks: W1, EWB1-3= female individuals; W2, EWJ1-3= male individuals; Seq.Div.= sequence divergence 
Dian Bhagawati et al. / Biosaintifika 12 (1) (2020): 104-110

Table 2. Kimura 2-parameter (K2P) genetic distances between individuals within and among species

\begin{tabular}{|c|c|c|c|c|c|c|c|c|c|c|c|c|c|}
\hline & W1 & $\mathrm{Ee}$ & W2 & EWB1 & EWB2 & EWB3 & EWJ1 & EWJ2 & EWJ3 & P1 & As & $\mathrm{Ap}$ & $\mathrm{Ag}$ \\
\hline \multicolumn{14}{|l|}{ W1 } \\
\hline $\mathrm{Ee}$ & 0.004 & & & & & & & & & & & & \\
\hline W2 & 0.002 & 0.002 & & & & & & & & & & & \\
\hline EWB1 & 0.002 & 0.002 & 0.000 & & & & & & & & & & \\
\hline EWB2 & 0.000 & 0.004 & 0.002 & 0.002 & & & & & & & & & \\
\hline EWB3 & 0.000 & 0.004 & 0.002 & 0.002 & 0.000 & & & & & & & & \\
\hline EWJ1 & 0.004 & 0.004 & 0.002 & 0.002 & 0.004 & 0.004 & & & & & & & \\
\hline EWJ2 & 0.002 & 0.005 & 0.004 & 0.004 & 0.002 & 0.002 & 0.005 & & & & & & \\
\hline EWJ3 & 0.002 & 0.002 & 0.000 & 0.000 & 0.002 & 0.002 & 0.002 & 0.004 & & & & & \\
\hline P1 & 0.256 & 0.253 & 0.256 & 0.256 & 0.256 & 0.256 & 0.256 & 0.256 & 0.256 & & & & \\
\hline As & 0.256 & 0.253 & 0.256 & 0.256 & 0.256 & 0.256 & 0.256 & 0.256 & 0.256 & 0.000 & & & \\
\hline Ap & 0.224 & 0.222 & 0.224 & 0.224 & 0.224 & 0.224 & 0.224 & 0.222 & 0.224 & 0.190 & 0.190 & & \\
\hline $\mathrm{Ag}$ & 0.230 & 0.233 & 0.230 & 0.230 & 0.230 & 0.230 & 0.233 & 0.233 & 0.230 & 0.209 & 0.209 & 0.217 & \\
\hline $\mathrm{Ss}$ & 0.262 & 0.259 & 0.262 & 0.262 & 0.262 & 0.262 & 0.262 & 0.262 & 0.262 & 0.253 & 0.253 & 0.237 & 0.290 \\
\hline
\end{tabular}

Remarks: W1-2, EWB1-3, EWJ1-3= mole crabs samples from north coast of Central Java, Ee= Emerita emeritus $\mathrm{KR} 047035, \mathrm{P} 1=$ mole crabs sample from south coast of Java, As= Albunea symysta, Ap= Albune aparreti, $\mathrm{Ag}=$ Albunea gibbessi, $\mathrm{Ss}=$ Scylla serrata

A low level of genetic distances among our samples indicated that our sample belongs to single species. Low genetic distance was also observed between all our samples with the reference sequences of $E$. emeritus (accession number KR047035), while the interspecies pairwise comparison showed high genetic distances (Table 1). Low genetic distance to the reference sequences becomes a strong indication that all the samples genetically identified as E. emeritus. This decision was performed based on several references. Pereira et al. (2013) found that genetic distances among individuals from single species ranged from 0.00 up to 0.085 . The low genetic distance of 0.002 was reported by Nuryanto et al. (2017) on two morphotypes larvae, which was suggested to belong to single species. Additional earlier studies also proved that individuals from single species had low genetic distances (Thirumaraiselvi et al., 2015; Hubert et al., 2012), even among conspecific specimens collected from geographically separated populations (Sachithanandam et al., 2012). Higher genetic distance among individuals from single species was reported in other groups of animals, such as in thrips (Kurniawaty et al., 2016), and in Lepidoptera (deWaard et al., 2011). It seems that genetic distances among intraspecific individuals varied among animal phyla. Nevertheless, previous studies have evidenced that intraspecific genetic distance was lower than interspecific specimens. Therefore, our inference that mole crab samples from the northern coast of Central Java that belong to E. emeritus based on low genetic distances to the reference E. emeritus (KR040735) species available in GenBank was undoubted.

The phylogenetic tree showed that all samples and conspecific references formed a monophyletic group
(Figure 2). The monophyly of the samples to the reference species had supported by a perfect bootstrap value of 100 . This value indicated that all trees (1000) that were reconstructed during the analysis had similar branching patterns for the monophyly of the samples and the reference species (E. emeritus KR047035).

The monophyly of our samples with reference species strengthens the previous decision that both samples belong to E. emeritus. Previous studies proved that individuals from single species form a clade in the phylogenetic tree if they are compared to their conspecific relatives and supported by high bootstrap value (Nuryanto et al., 2017; Kurniawaty et al., 2016; Victor et al., 2009).

The presence of E. emeritus had been reported from several coastal areas in Indonesia (Pramithasari et al., 2017; Wardiatno et al., 2015; Mashar \& Wardiatno, 2013). However, the existence of E. emeritus on the northern coast of Central Java had never been reported. Therefore, the success of the COI barcoding of mole crab samples from the northern coast of Central Java, as resulted in this study, proved that mole crabs E. emeritus exist in that coastal area. Our finding was the first record of the existence of Emerita emeritus on the northern coast of Central Java Province.

The data on the existence of E. emeritus on the north coast of Central Java is valuable for the management of sustainable use of that natural resource in the area. The data also provide additional evidence that molecular systematic is a valuable tool for biodiversity assessment, especially for species-level identification in highly polymorphic species, such as mole crabs. 


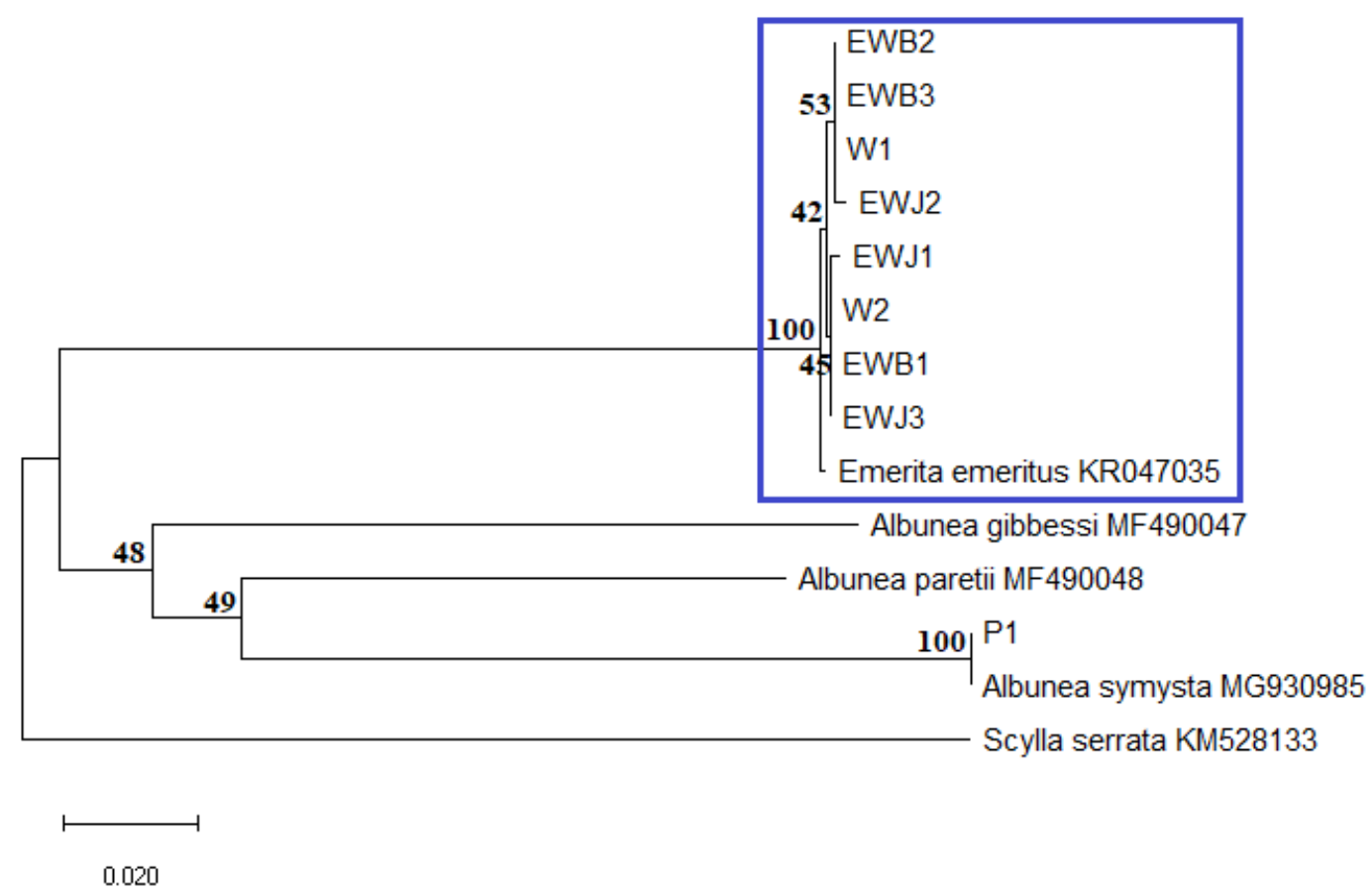

Figure 2. Phylogenetic tree showing the monophyly of the mole crab samples and conspecific species fished from GenBank (blue squares)

\section{CONCLUSION}

Based on high homology value, low genetic distance, and monophyly of our samples with the reference sequences, it can be concluded that mole crab Emerita emeritus exists on the northern coast of Central Java. This result was the first report of the existence of mole crabs on the north coast of Central Java.

\section{ACKNOWLEDGMENTS}

We would like to thanks the Research and Public Service Institute of Universitas Jenderal Soedirman for providing the funding through the research scheme of Riset Kompetensi 2019. We also deliver high appreciation to the Dean of Biology faculty for his support and for giving permits to do this research. We also thank fishermen who help the researchers during sampling. Finally, we acknowledged the reviewers for their contributions to raising the scientific sound of this manuscript.

\section{REFERENCES}

Beasley, J.C., Olson, Z.H. \& deVault, T.L. (2012). Carrioncyc lignin food webs: comparisons among terrestrial and marine ecosystems. Oikos, 121, 1021-1026.

Bhagawati, D., Anggoro, S., Zainuri, M., \& Sya'rani, L. (2016). Ethno taxonomical study of mole crab
(Crustacea: Hippoidea) on coastal community of Cilacap. Biosaintifika, 8(2), 222-230.

Bilgin R., Utkan, M.A., Kalkan, A., Karhan, S.U., \& Bekbolet, M. (2014). DNA barcoding of twelve shrimp species (Crustacea: Decapoda) from Turkish seas reveals cryptic diversity. Mediterranean Marine Science, 16(1), 36-45.

Boyko, C.B. \& Mc Laughlin, P.A. (2010). Annotated checklist to anomuran Decapods crustaceans of the world (exclusive of the Kiwaoidea and families Chirostylidae and Galatheidae of the Galatheoidae) Part IV- Hippoidea. The Raffles Bulletin of Zoology, 23, 139-151.

Bucklin, A., Hopcroft, R.R., Kosobokova, K.N., Nigro, L.M., Ortman, B.D., Jennings, R.M., \& Sweetmann, C.J. (2010). DNA barcoding of Arctic Ocean holozooplankton for species identification and recognition. Deep-Sea Research II, 57, 40-48.

da Silva, J.M., Creer, S., dos Santos, A., Costa, A.C., Cunha, M.R., Costa, F.O., \& Carvalho, G.R. (2011). Systematic and evolutionary insights derived from mtDNA COI barcode diversity in the Decapoda (Crustacea: Malacostraca). PLoS ONE, 6(5), e19449. doi:10.1371/journal.pone.0019449.

deWaard, J.R., Hebert, P.D.N., \& Humble, L.M. (2011). A comprehensive DNA barcode library for the looper moths (Lepidoptera: Geometridae) of British Columbia, Canada. PLoS ONE,6(3), 1-6.

Folmer, O., Black, M., Lutz, R., \& Vrijenhoek, R. (1994). DNA primers for amplification of mitochondrial cytochrome $\mathrm{c}$ oxidase subunit I from 
metazoan invertebrates. Mol. Mar. Biol. Biotechnol., 3(5), 294-299.

Hall, T.A. (1999). BioEdit: A user-friendly biological sequence alignment editor and analysis program for Windows 95/98/NT. Nucleic Acids Symposium Series, 41, 95-98.

Hubert, N., Meyer, C.P., Bruggeman, H.J., Guerin, F., Komeno, R.J.L., Espiau, B., Caussee, R., Wiliams, J.T., \& Planes, S. (2012). Cryptic diversity in Indo-Pacific coral reef fishes revealed by DNA barcoding provides new support to the center-ofoverlap hypothesis. PloS One, 7(3), e28987.

Ko, H.L., Wang, Y.T., Chiu, T.S., Lee, M.A., Leu, M.Y., Chang, K.Z., Chen, W.Y., \& Shao, K.T. (2013). Evaluating the accuracy of morphological identification of larval fishes by applying DNA barcoding. Plos One,8(1), e53451.

Kumar, S., Stecher, G., Li, M., Knyaz, C., \& Tamura, K. (2018). MEGA X: Molecular Evolutionary Genetics Analysis across Computing Platforms. $\mathrm{Mo}$ lecular Biology and Evolution, 35(6), 1547-1549.

Kurniawaty, N., Hidayat, P. \&Rauf, A. (2016).Characterization of three Species of thrips on banyan, nutmeg, and marine seruni plants based on COI gene. Biosaintifika: Journal of Biology \& Biology Education, 8(2), 185-192.

Lastra, M., López, J., Troncoso, J., Hubbard, D.M., \& Dugan, J. E. (2016). Scavenger and burrowing features of Hippa pacifica (Dana1852) on a range of tropical sandy beaches. Marine Biology, 163(10).

Mahapatro, D., Karna, S.K., Mohanty, S.K., Mohanty, B., Muduli, P.R., Pattnaik, A. K., \& Nanda, S. (2018). First record of a burrowing mole crab Emerita emeritus (Decapoda: Anomura: Hippidae) from Chilika Lake, East coast of India. Indian Journal of Geo-Marine Sciences, 47(01), 109-113.

Mashar, A. \& Wardiatno, Y. (2013). Aspect of mole crab growth of Emerita emeritus from sandy beach of Kebument Regency. Jurnal Biologi Tropis, 13(1), 29-38. [in Indonesia].

Mantelatto, F.L., Carvalho, F.L., Simoes, S.M., Negri, M., Souza-Carvalho, E.A., \& Terossi, M. (2016). New primers for amplification of cytochrome c oxidase subunit I barcode region designed for species of Decapoda (Crustacea). Nauplius, 24, e2016030.

Muzammil, W., Wardiatno, Y., \& Butet, N.A. (2015). Carapace length-width ratio, growth pattern, condition factor, and relative condition factor of the sand crab (Hippa adactyla) in sandy beach of Cilacap and Kebumen. Jurnal Ilmu Pertanian Indonesia, 20(1), 78-84. [inIndonesian].

Nuryanto, A., Pramono, H., \& Sastranegara, M.H. (2017). Molecular Identification of Fish Larvae from East Plawangan of Segara Anakan, Cilacap, Central Java, Indonesia. Biosaintifika, 9(1), 33-40.
Pereira, L.H.G., Hanner, R., Foresti, F., \& Oliveira, C. (2013). Can DNA barcoding accurately discriminate mega diverse Neotropical freshwater fish fauna? BMC Genetics, 14(20),1-14.

Pramithasari, F. A., Butet, N. A., \& Wardiatno, Y. (2017). Variation in morphometric characters in four sand crab (Albunea symysta) populations collected from Sumatra and Java Island, Indonesia. Tropical life sciences research, 28(1), 103.

Raupach, M.J., Barco, A., Steinke, D., Beermann, J., Laakmann, S., Mohrbeck, I., Neumann, H., Kihara, T.C., Pointner, K., Radulovici, A., SegelkenVoigt, A., Wesse, C., \& Knebelsberger, T., (2015). The application of DNA barcodes for the identification of marine crustaceans from the North Sea and adjacent regions. PLoS ONE 10(9): e0139421.

Rudolf, N.R., Haug, C., \& Haug, J.T. (2016). Functional morphology of giant mole crab larvae: a possible case of defensive enrollment. Zoological Letters, 2, 17. DOI 10.1186/s40851-016-0052-5.

Sachithanandam, V., Mohan, P. M., Muruganandam, N., Chaaithanya, I. K., Dhivya, P., \&Baskaaran, R. (2012). DNA barcoding, phylogenetic study of Epinephelus spp. from Andaman Coastal Region, India. Indian Journal of GeoMarine Sciences, 41(4), 203-211.

Thompson, J.G., Higgins, D.G., \& Gibson, T.J. (1994). CLUSTALW: improving the sensitivity of progressive multiple sequence alignments through sequence weighting, position-specific gap penalties, and weight matrix choice. Nucleic Acids Research, 22, 4673-4680.

Thirumaraiselvi, R., Das, S., Ramanadevi, V., \& Thangaraj, M. (2015). MtDNA barcode identification of Fisnfish larvae from Vellar Estuary, Tamilnadu, India. Notulae Scientia Biologicae, 7(1), 16-19

Victor, B. C., Hanner, R., Shivji, M., Hyde, J., \& Caldow, C. (2009). Identification of larval and juvenile stages of the cubera snapper, Lutjanus cyanopterus, using DNA barcoding. Zootaxa, 2215(2), 24-36.

Ward, R.D., Hanner, R., \& Hebert, P.D.N. (2009). The campaign to DNA barcode all fishes, FISHBOL. Journal of Fish Biology, 74, 329-356.

Wardiatno, Y., Ardika, P.U., Farajallah, A., Butet, N.A., Mashar, A., Kamal, M.M., Renjaan, E.A. (2015). Biodiversity of Indonesian sand crabs (Crustacea, Anomura, Hippidae) and assessment of their phylogenetic relationships. AACL Bioflux, 8(2), 224-235.

Wardiatno, Y., Nurjaya, I.W., \& Mashar, A. (2014). Karkateristik habitat undur-undur laut(Famili Hippidae) di pantai berpasir, Kabupaten Cilacap. J.Biol.Tropis, 14(1), 1-8. 
Wardiatno, Y., Qonita, Y., \& Hakim, A.A. (2016). Burrowing time of the three Indonesian hippoid crabs after artificial dislodgment. Indonesian Journal of Marine Sciences, 21(3), 135-142.

Weiss, M., Macher, J.N., Seefeldt, M.A., \& Leese, F. (2014). Molecular evidence for further overlooked species within the Gammarus fossarum complex (Crustacea: Amphipoda). Hydrobiologia, 721, 165-184.

Wilson, E.E. \& Wolkovich, E.M. (2011). Scavenging: how carnivore sand carrion structure communities. Trends Ecol Evol, 26, 129-135. 